\title{
Impact of Corporate Social Responsibility Implementation in Jordanian Public Shareholding Companies on Sustainable Development
}

\author{
Ismail Al-Zyoud ${ }^{1}$ \\ ${ }^{1}$ University of Jordan, Jordan \\ Correspondence: Ismail Al-Zyoud, Associate Professor, University of Jordan. E-mail: abadi_ismail@yahoo.com
}

Received: November 14, 2016

Accepted: December 5, 2016

Online Published: January 19, 2017

doi:10.5539/ass.v13n2p94

URL: http://dx.doi.org/10.5539/ass.v13n2p94

\begin{abstract}
The study aimed to investigate the impact of corporate social responsibility implementation in Jordanian public shareholding companies on sustainable development. The study used descriptive analytical methodology. A questionnaire was designed and distribute over a sample consisting of 135 reponsedents, 125 were collected and 5 questionnaires were removed. The study results indicated that there a statistically significant impact at the level of significance $(\alpha \leq 0.05)$ of social responsibility in Jordanian public shareholding companies on sustainable development. It also indicated that there is a statistically significant impact at the level of significance $(\alpha \leq 0.05)$ of economic, legal, ethical and philanthropic responsibility responsibility in Jordanian public shareholding companies on sustainable development. The study recommended a set of recommendations.
\end{abstract}

Keywords: Corporate, social responsibility, Public shareholding companies, legal, economic, ethical and philanthropic, and sustainable development

\section{Introduction}

The field of corporate social responsibility has grown considerably over the last decade. Many businesses are becoming more active in contributing to society now than used to be the case. Corporate social responsibility issues are now being integrated into all aspects of business operations and explicit commitment to CSR is made in the visions, missions and value statements of an increasing number of companies all over the world. Corporate social responsibility reports issued usually go beyond profit maximization to include the company's responsibilities to a broad range of stakeholders including employees, customers ,community and the environment. It is worth to mention that corporate social responsibility has four types namely: economic responsibility, legal responsibility ethical responsibility and Philanthropic responsibility.

Corporate social responsibility and sustainability are among the most widely researched areas of business research, particularly there are various studies that address CSR and sustainability either issues in specific industries or in the worldwide economy (Riasi \& Purmiri, 2016).

\subsection{Study Problem}

As a result of increased attention to social responsibility the majority of companies in various countries around the world either advanced or developing are facing a lot of social and economic challenges and bear their responsibilities and its interaction with the community in which they operates. The study problem is to answer the following question: What is the role of social responsibility of Jordanian share holding companies in sustainable development.

\subsection{Study Questions}

1. Does Jordanian public shareholding companies practicing corporate social responsibility?

2. What are the most important social activities of Jordanian public shareholding companies?

3. What are the most important development aspects carried out by Jordanian public share holding companies?

\subsection{The Importance of the Study}

The study importance stems from the importance of the topic it handles represented by determining the impact of the social responsibility in adoption in Jordanian public share holding companies on sustainable development. The important also is due to lack of studies on the impact of social responsibility on sustainable development at 
the local level.

\subsection{Study Objectives}

This study aims to identify the role of social responsibility with its dimensions (economic, legal, ethical and philanthropic) for Jordanian public shareholding companies to contribute to sustainable development, as well as to achieve the following sub-goals:

1-To find out the most important social activities that Jordanian shareholding companies carry out.

2-To investigate the disclose extent of the social activities carried out by Jordanian public shareholding companies

3-To specify the most effective dimension of corporate social responsibility that influence sustainable development

\subsection{Hypotheses Development}

There is a relationship between sustainability, sustainable development and social responsibility: The existing definitions tend to imply that all the attempts are to lead us to the long term objective of sustainability and that you therefore act socially responsible in a company or organization aligned with the greater aim of society called sustainable development and these are all to attain sustainability. Therefore the main hypothesis is derive $\mathrm{d}$ as follows:

Ho - There is no impact of social responsibility with its dimensions in Jordanian public shareholding companies (economic, legal, ethical, philanthropic) in sustainable development

The following sub-hypotheses are derived

Companies are economic entities established to provide goods and services to society. Profit maximization is the main goal for any business. Therefore, managers are obliged to maximize shareholders wealth, therefore they participates in dourty's development, so the first hypothesis is developed as follows

Ho1 - There is no impact of economic responsibility in Jordanian public shareholding companies on sustainable development

Firms are expected to comply with laws and regulations. Legal responsibility includes basic notions of fair operations. Carroll's legal component stresses on the need for any firm to: perform its targets in a manner consistent with expectations of government and law; so it should provide goods and services that meet minimal legal requirements; and that a successful firm be defined as one that fulfils its legal obligations, therefore the second sub hypothesis is derived as follows

Ho2 - There is no impact of legal responsibility in Jordanian public shareholding companies on sustainable development

Ethical responsibility refer to strategic managers' values about right and wrong business behavior or conduct. Ethics or values are dynamic and precede the establishment of law. Therefore ethics are the driving force behind the creation of laws or regulations. Moreover, ethical responsibilities embrace society emerging values and norms which a business are expected to meet. Sometimes, such values and norms may require a higher standard of performance than that required by law. This in its turn will enhance sustainable development

Ho3 - There is no impact of ethical responsibility in Jordanian public shareholding companies on sustainable development

Philanthropic responsibilities are voluntarily assumed by business; such as public relations, good citizenship, and contribution to education or community.. Philanthropy is voluntary in which firm: performs in a manner consistent with philanthropic and charitable expectations of society, and voluntarily assist projects that enhance a community's quality of life, which enhance sustainable development, so the fourth sub hypothes0s is derived as follows:

Ho4 There is no impact of philanthropic responsibility in Jordanian public shareholding companies on sustainable development

\subsection{Social Responsibility Concept}

There is no agreement on corporate social responsibility definition (Taneja et al., 2011). It is worth noting that corporate social responsibility is different, as some organizations indicate that social responsibility is the social organizational performance, companies social response, corporate citizenship, business and ethical practices, stakeholders management, corporate sustainable business practices (Sharma \& Kiran, 2013). Corporate social 
responsibility indicates that companies have responsibilities which extends beyond making profit for the community. Despite this, the company has social responsibilities, and it is morally responsible for its work because strategic decisions affect stakeholders. The company must be accountable to stakeholders, even if it requires to scarify with some of its profits. Companies have to deal with these interests and conflicting demands in an ethical manner through formulating friendly policies with stakeholders. This is consistent with Carroll and Buchholz (2011) in confirming that corporate social responsibility includes economic, legal, ethical and philanthropic expectations, imposed on the company by the community.

Social responsibility is organization's commitment with its performance in economic method social and permanent environmental and at the same time to balanced the various interests stakeholders (Siwar \& Hossain, 2009, p. 290)

Changiz, (2013) indicated that social responsibility is the goal for perfection, which cannot be achieved since it is a goal of continuous improvement. And it is the regulatory actions and decisions regarding community social responsibility continuity and environmental sustainability of which they operate. The global commercial chamber defined CSR as "all attempts that contribute to companies volunteer to achieve development because of ethical and social considerations. Therefore social responsibility initiatives depend on business men goodwill without a legally binding procedures." And so the social responsibility is achieved through persuasion and education (Al-Sakarneh, 2009, p. 167).

The international standards organization ( ISO) defined social responsibility as " organization responsibility on the consequences of its decisions and activities on society and the environment through transparency and ethical behavior that fit with sustainable development and community welfare as well as taking into account the expectations of shareholders (ISO26000, 2007)

Social responsibility is defined as a concept through which the company offers continuously responsible activities that point to good intention as a citizen Company. It also defined as a situation where the company will carried out actions that appear to promote some social good away from company's interest legally required (Amole et al., 2012).

Many studies confirmed the importance of social responsibility. For example a study conducted in the United States in 2006 indicated that $\$ 2.3$ trillion, of $\$ 24$ trillion was invested in companies that showed the proportion of studies high scale within the corporate social responsibility (Heslin \& Ochoa, 2008).

\subsection{Benefits of Social Responsibility}

Implementation of corporate social responsibility provides the companies with the following benefits (United Nations, 2004, p. 75):

1. Improve Financial Performance: There is a relationship between socially responsible practices for companies and financial positive performance.

\section{Reducing operating costs:}

There are many efforts in companies social responsibility regarding human resources, which leads to employees absence ratio reduction, and increase large number of staff retention a who are highly motivated to work, effectiveness and productivity efficiency, and reduce recruitment and training costs.

3. Enhancing brand reputation and image: companies that implement social responsibility benefit in enhancing its reputation among public and promote its ability to attract capital and business partners and find wide area in global market competition.

4. Enhancing sales and customer loyalty. studies demonstrate the increasing desire to buy or not to buy because of some other standards-based on values such as the lack of impact on environment, and not using materials or components.

5. Increased productivity and quality: efforts exerted by companies in implementing social responsibility increase productivity and reduce rate errors of occurrence, enhance effectiveness and efficiency by improving working conditions and increase employee participation in decision-making.

6. Increase the ability to attract and retain staff: companies that implement CSR can easily recruit highly skilled individuals and maintain them, this leads to reduce recruitment and training costs.

7. Reducing organizational control: companies that meet regulatory compliance requirements give more amount of discretion by national government or local entities. 


\subsection{Types of Social Responsibility}

There are four types of social responsibility, management should take into account these types when taken into account the implementation of any meaningful strategy (Choi \& Gray, 2008, p. 345).

Below a short brief of these types:

\subsubsection{Economic Responsibility}

It refers to maximize the industrial companies profitability and shareholders' equity, and fair payment for employees, the sale of goods and services at affordable prices, and payment to suppliers in a timely manner, and appropriate investment in the communities in which it operates (Choi \& Gray, 2008, p. 345)

\subsubsection{Philanthropic Responsibility}

Philanthropy responsibility includes corporate actions, towards promoting human welfare or goodwill, in response to society's expectations that businesses should be good corporate citizens. It is voluntarily assumed by business.. The main difference between philanthropic and ethical responsibilities is that ethical components are expected in an ethicalor moral sense, but philanthropic components are not. Philanthropy is voluntary or discretionary on the part of a business (Mehran \& Sasan, 2012).

\subsection{Legal Responsibility}

It refers to the commitment of industrial companies legally, pay taxes and abide with legislation to protect the environment and the customer. It is known that companies pay too much in an attempt to ensure compliance with this legislation (Alan, 2011, p 233)

\subsection{Ethical Responsibility}

It refers to behavioral beliefs that form contributions or activities expected to be carried out by industrial companies towards the community, such as alternative plans, such as firing the employees and search for alternative jobs for them (Pava, 2008, p. 807).

\subsection{Social Responsibility Successful Implementation Factors}

Business organizations in order to succeed in social responsibility implementation, there are several key factors that must be prepared and organized before launch these programs, particularly the following (Rawabdeh \& Ababneh, 2010, p. 126).

1. The need for availability of full conviction of top management of social responsibility towards the community and its employees and beneficiaries of their services and products.

2. The need for institutional clear vision of social responsibility dimensions and its activities, and to develop appropriate future plans and consider it as policy institution that must be practiced

The need for a full-time person or entity, and specialized to carry out the social role, and the link may be with top management to give it the clear interest.

\subsection{Dimensions of Social Responsibility}

Business organizations are practicing number of social responsibilities, which fall under two categories namely: ethical, and humanity towards the local community, employees, customers, suppliers, the environment, and shareholders. The ethical responsibility is obligatory responsibility and it exceeds the fulfillment of legal and economic obligations..

\subsubsection{Social Responsibility towards Local Community}

Social responsibility includes contribute to infrastructure support, bridges and parks building, contribute to the reduction of the unemployment problem, support activities such as recreational clubs, respect local customs, civil society institutions support, and providing money support for special needs people, in addition to continued support for scientific centers such as research centers and hospitals, and it may includes charity sponsorship, sports, art, education and training institutions, and establishment local development projects (Anselmsson \& Johansson, 2007).

\subsubsection{Social Responsibility towards Employees}

This responsibility is represented by providing the best for employees since social responsibility has become among the factors that employees with high skills focus Employees majority prefer to work in organization that has good environmental and community policies (Eweje \& Bentley, 2006)

Social responsibility towards customers 
This segment of society has great importance to all organizations, without exception. The social performance that directed to this segment is to provide product with suitable prices, qualities, and credible advertising. Providing friendly and safe products, in addition to providing clear guidance regarding the use of the product, and organizations commitment to address damage that occur after sale, and constantly develop products in addition to the moral obligation of non breaching rules, such as monopoly (Haddad, 2006).

\subsubsection{Social Responsibility towards Suppliers}

The relationship between suppliers and business organizations is a relationship of mutual interests, therefore suppliers expect that business organizations respect their legitimate aspirations and demands, which can be summarized by continues supply, especially for certain types of required raw materials for production processes, and fair prices fair and acceptable for supplied materials to business organizations as well to repay obligations, honesty in dealing, and training suppliers on different work development methods (Ghalibi \& Ameri, 2005).

\subsubsection{Social Responsibility towards the Environment}

Carrigan and Attalla, (2001) argued that the social responsibility includes the imposed environment systems namely within the organization philosophy and environmental reports.

\subsubsection{Social Responsibility towards Shareholders}

Shareholders category o is deemed an important category of stakeholders beneficiaries from organization's activity. The organization's responsibility towards them is to achieve maximum profit, to maximize share value, increase sales volume, as well as to protect organization's assets and assets (Haddad, 2006).

\subsection{Sustainable Development}

Sustainable development has emerged as type of development for the purpose of helping world states to overcome current and future environmental and social challenges, among which are climate change, energy resources, and water scarcity Development is the "organized exerted efforts that are being made in accordance with placed organization for coordination between human and material resources available in a particular social environment in order to achieve a higher national income and individual incomes and higher standards of living level and social life in different aspects to achieve the highest possible level of social welfare, which should be performed without cultural personality peoples distortion" (2013 Hiti, 2013, p. 14).

\subsubsection{Sustainable Development Goals}

Sustainable Development Goals, has been launched in 2015 in the United Nation's publication transforming our World (UN, 2015), The publication indicated the following goals:

1. End poverty in all its forms everywhere: End hunger, achieve food security and improved nutrition and promote sustainable agriculture

2. Ensure healthy lives and promote well-being for all at all ages

3. Ensure inclusive and equitable quality education and promote lifelong learning opportunities for all

4. Achieve gender equality and empower all women and girls

5. Ensure availability and sustainable management of water and sanitation for all

6. Ensure access to affordable, reliable, sustainable and modern energy for all

7. Promote sustained, inclusive and sustainable economic growth, full and productive employment and decent work for all

8. Build resilient infrastructure, promote inclusive and sustainable industrialization and foster innovation

9. Reduce inequality within and among countries

10. Make cities and human settlements inclusive, safe, resilient and sustainable

11. Take urgent action to combat climate change and its impacts*

12. Conserve and sustainably use the oceans, seas and marine resources for sustainable development

13. Protect, restore and promote sustainable use of terrestrial ecosystems, sustainably manage forests, combat desertification, and halt and reverse land degradation and halt biodiversity loss

14. Promote peaceful and inclusive societies for sustainable development, provide access to justice for all and build effective, accountable and inclusive institutions at all levels

15. Strengthen the means of implementation and revitalize the global partnership 


\subsubsection{Sustainable Dimensions}

Sustainable development has three dimensions as follows; (Othman \& Majeda, 2007)

1-Economic dimension: Economic of sustainable development includes the following:

- Be profitable.

- Manage the costs to customers and consumers to use our products.

- Make products that people want.

- Support our communities by buying local goods and services, paying taxes and participating in local activity

\section{2- Social Dimensions}

Social dimensions represents the human dimension and includes the following:

- Make products that improve people's lives.

- Support the communities in which we live and work.

- Maintain quality work environments.

- Source materials responsibly.

3- Environmental Dimension

This dimension includes the following:

- Use resources wisely.

- Comply with laws.

- Minimize our facilities' impact by operating safely, responsibly and efficiently.

- Reduce the adverse impact of our products in use.

\section{Literature Review}

Elasraj (2015) study investigated the role of private sector social responsibility in sustain development in the kingdom of Saudi Arabia, the study concluded that there is a growing increase of social responsibility of private sector concern in the kingdom and it has the priority in terms of changing companies to partners in sustain able development

Youssoufou (2014) study aimed to contribute in understanding issues related to Corporate Social Responsibility in Sub-Saharan Africa. The study demonstrates that despite multinationals strategies participate with economic and social development, there still is much to do given environmental, social and economic expectations.

Abdul Moyer, (2014) study aimed s to explore the attitudes and perceptions of senior managers in Bangladesh with regard to corporate social responsibility focusing on the impact of CSR promotional programmers in fostering an affirmative view of sustainable development. The study revealed that positive attitudes indicated that, sustainable development and environmental issues tend to remain on the periphery of managers' understandings and perceptions of CSR.

Seidu (2014) investigated how responsible businesses are practiced by European SMEs in Kenyan agribusiness and how their practices contribute to sustainable local development in Kenya. The study revealed that social responsibility practices have a positive impact on sustainable local development of the local communities within which the enterprises operate.

Sam and Bernard (2013) study aimed to assess the relation between corporate social responsibility and community development. The study concluded that the company implement corporate social responsibility and it also revealed that appropriate implementation $\mathrm{t}$ can result in considerable contribution to community development

\section{Research Methodology}

The study used the descriptive analytical approach for the purpose of investigating the impact of social responsibility in Jordanian public share holding companies on sustainable development

\subsection{Population and Sampling}

The study population consists of all managerial staff in Jordanian companies a random sample was selected. 135 questionnaire were distributed $\mathrm{m}$ an 5 were collected and 5 questionnaire were disregarded due to incomplete 
information, therefore the response rate was $81.2 \%$.

\subsection{Data Sources}

The study used primary and secondary sources as follows:

Secondary sources: The study used books, references and periodicals, theses and doctoral dissertations that discuss the topic of social responsibility and sustainable development

The primary sources: The study used the questionnaire that was designed in accordance with the objectives and hypotheses of the study

\subsection{Data Analysis}

All collected data were coded and then analyzed by using Statistical Package of the Social Sciences (SPSS) the following statistical analysis will be used

1- Descriptive statistics will be used for the purpose of obtaining frequencies, percent's of demographic variables.

2-Central tendency Measures (means and standard deviations) for sample's responses on the questionnaire statements and to find out the relative importance of independent variables

3-Furthermore a t- test will be used to find the influence of independents variable on the dependent variables

\subsection{Research Validity}

The questionnaire was proof-read by a panel of university instructors, their comments and amendments were taken in consideration. Their comments led to some $f$ changes in the instrument statement. Therefore some items were eliminated or added to form the final form of the questionnaire.

\subsection{Research Reliability}

Cronbach Alpha was used to measure the used instrument reliability, Table (1) indicate the reliability values.

Table 1.

\begin{tabular}{|c|c|c|c|}
\hline \multicolumn{2}{|c|}{ Variables } & Cronbach alpha & No. of items \\
\hline \multirow{3}{*}{ Independent variables } & Economic & 92.2 & 6 \\
\hline & Legal & 92.9 & 6 \\
\hline & Ethical & 94.8 & 6 \\
\hline \multirow{3}{*}{ Dependent Variables } & Philanthropic & 94.2 & 6 \\
\hline & Sustainable Development & 95.2 & 8 \\
\hline & Total Instrument & $\% 98.3$ & 32 \\
\hline
\end{tabular}

Table 2. Sample distribution according to Demographic information

\begin{tabular}{lcc}
\hline \multicolumn{1}{c}{ Variable } & Frequency & Percentage\% \\
\hline Age & 37 & 30.8 \\
Less than 30 years & 43 & 35.8 \\
30 to less than 40 years & 27 & 22.5 \\
40 to less than 50 years & 13 & 10.8 \\
$50+$ & & \\
Educational level & 79 & 65.8 \\
BSC. & 41 & 34.2 \\
MSC & 00 & 00 \\
PHD & & \\
Years of experience & 58 & 48.3 \\
Less than 5 years & 42 & 35.0 \\
5- to less than 10 years & 10 & 8.3 \\
10 to less than 15 years & 10 & 8.3 \\
15+ & & \\
Job Title & 34 & 28.3 \\
Manger & 32 & 26.7 \\
Deputy manager & 54 & 45.0 \\
Relationship Manager & & \\
\hline
\end{tabular}


Age ranged from less than 30 years to $50+$ years. $30.8 \%$ were less than 30 years, $35.8 \%$ were of the group between 30 to less than 40 years, $22.5 \%$ were between 40 to less than 50 years, and $10.8 \%$ were 50 years and more. With regard to education, the respondent majority were university educated, $65.8 \%$ possessing bachelor degree and $34.2 \%$ percent possessing MSC degree. As for years of experience $48.3 \%$ of research subjects were have (less than 5 years), $35 \%$ have between ( 5 to less than 10 years ) and $8.3 \%$ have (10 to less than 15 years ) while $8.3 \%$ have (15+ years) As for job title $28.3 \%$ of the sample was manager, while $26.7 \%$ were deputy managers, and $45 \%$ were relationships manager.

Table 3. Means and standard deviations of sample's responses regarding Economic Responsibility

\begin{tabular}{clcccc}
\hline No. & \multicolumn{1}{c}{ Question } & Mean & S.D & Rank & Level \\
\hline 1 & The company provides training program for its workers to raise their productivity & 3.43 & 1.400 & 4 & Medium \\
2 & The company focuses on economic resource development & 3.63 & 1.348 & 1 & High \\
3 & The company offers financial support to development activities & 3.61 & 1.292 & 2 & High \\
4 & The Company has strategy to achieve sustainable development & 3.42 & 1.178 & 5 & Medium \\
5 & The Company has programs to develop the skills and efficiency of workers & 3.38 & 1.094 & 6 & Medium \\
6 & The company supports rural development project & 3.48 & 1.085 & 3 & Medium \\
& General Mean & 3.49 & 1.05 & High \\
\hline
\end{tabular}

Table (3) shows that means of sample subjects' responses ranged between (3.38- 3.63) with standard deviations (1.085 and 1.292) respectively. The results indicate medium degrees of sample's agreement. Table also indicated that statement no. (2) "The company focuses on economic resource development." ranked the first, while statement no. (5) " The Company has programs to develop the skills and efficiency of workers" ranked the last.

Table 4. Means and standard deviations of sample's responses regarding legal Responsibility

\begin{tabular}{|c|c|c|c|c|c|}
\hline No. & Question & Mean & S.D & Rank & Level \\
\hline 7 & The company is committed to the legislation in force in the kingdom. & 3.52 & 1.174 & 4 & Medium \\
\hline 8 & The company is committed in force in the Jordan Social Security Law & 3.61 & 1.007 & 1 & Medium \\
\hline 9 & The company is committed to the application of environmental conservation laws & 3.58 & .984 & 2 & Medium \\
\hline 10 & The company is working on the available environmental resources development & 3.51 & 1.108 & 5 & Medium \\
\hline 11 & The company avoids discrimination between workers & 3.58 & 1.097 & 3 & Medium \\
\hline \multirow[t]{2}{*}{12} & The company applied occupational safety instructions & 3.33 & 1.168 & 6 & Medium \\
\hline & General Mean & 3.52 & 0.938 & & \\
\hline
\end{tabular}

Table (4) shows that means of sample subjects' responses ranged between (3.33- 3.61) with standard deviations (1.168 and 1.007) respectively. The results indicate medium, degrees of sample's agreement. Table also indicated that statement no. (7) "The company is committed in enforce he Jordan Social Security Law." ranked the first, while statement no. (11) "The company applied occupational safety instructions" ranked the last..

Table 5.Means and standard deviations of sample's responses regarding ethical Responsibility

\begin{tabular}{clcccc}
\hline No. & \multicolumn{1}{c}{ Question } & Mean & S.D & Rank & Level \\
\hline 13 & The company is keen on application of justice in workers selection & 3.50 & 1.115 & 5 & Medium \\
14 & The company is committed to tradition and societal norms & 3.45 & 1.107 & 6 & Medium \\
15 & The company resist any workers non ethical practice & 3.58 & 1.026 & 2 & Medium \\
16 & The company is committed to providing free of fraud and forgery products & 3.55 & 1.091 & 4 & Medium \\
17 & The company keeps the secrets of their clients & 3.59 & 1.111 & 1 & Medium \\
18 & Company's propaganda campaigns are honest & 3.57 & 1.158 & 3 & Medium \\
& General Mean & 3.540 & 0.981 & & \\
\hline
\end{tabular}

Table (5) shows that means of sample subjects' responses ranged between (3.45- 3.55) with standard deviations (1.107 and 1.111) respectively. The results indicate medium degrees of sample's agreement. Table also indicated that statement no. (17) "The company keeps the secrets of their clients" ranked the first, while statement no. (14) "The company is committed to tradition and societal norms" ranked the last. The general Responses indicate Jordanian public shareholding companies commitment of implementing ethical responsibility toward the community they work in. 
Table 6. Means and standard deviations of sample's responses regarding philanthropic Responsibility

\begin{tabular}{clcccc}
\hline No. & \multicolumn{1}{c}{ Question } & Mean & S.D & Rank & Level \\
\hline 19 & The company participates in social charity events & 3.53 & 1.152 & 6 & Medium \\
20 & The company supports infrastructure projects & 3.48 & 1.123 & 7 & Medium \\
21 & The company is sponsoring some charity events. & 3.59 & 1.025 & 4 & Medium \\
22 & The company helps in teaching employees children & 3.66 & 1.111 & 1 & Medium \\
23 & The company provides employment opportunities for people with special needs. & 3.63 & 1.108 & 2 & Medium \\
24 & The company provides outreach programs to support the environment in the & 3.55 & 1.083 & 5 & Medium \\
& development process & 3.63 & 1.061 & 3 & Medium \\
& The company trained workers have to protect the environment & 3.57 & 0.970 & & \\
\hline
\end{tabular}

Table (6) shows that means of sample subjects' responses ranged between (3.48- 3.66) with standard deviations (1.123 and 1.111) respectively. The results indicate medium degrees of sample's agreement from medium to high level. Table also indicated that statement no. (22) "The company helps in teaching employees children" ranked the first, while statement no. (20) "The company supports infrastructure projects" ranked the last.

Table 7. Means and standard deviations of sample's responses regarding Sustainable development

\begin{tabular}{llllll}
\hline No. & Question & Mean & S.D & Rank & Level \\
\hline 26 & The company will help in the economic development of resources & 3.66 & .992 & 2 & Medium \\
27 & The company uses human resources in good form & 3.52 & 1.053 & 7 & Medium \\
28 & The company put a plan of action to contribute to the development & 3.62 & 1.078 & 4 & Medium \\
29 & The company helps regulate population growth & 3.55 & 1.114 & 6 & Medium \\
30 & The company helps in reducing rural immigration & 3.60 & 1.056 & 5 & Medium \\
31 & The company trains employees to protect resources & 3.68 & 1.014 & 1 & High \\
32 & The company provides the necessary databases & 3.41 & 1.104 & 8 & Medium \\
33 & The company is keen in using environmentally friendly technology & 3.65 & 1.078 & 3 & Medium \\
& General Mean & $\mathbf{3 . 5 8}$ & $\mathbf{0 . 9 1 6}$ & \\
\hline
\end{tabular}

Table (7) shows that means of sample subjects' responses ranged between (3.41-3.68) with standard deviations (1.104 and 1.014) respectively. The results indicate different degrees of sample's agreement from medium to high level. Table also indicated that statement no. (30) "The company trains employees to protect resources" ranked the first, while statement no. (31) " The company provides the necessary databases" ranked the last.

\section{Results of Main Hypothesis}

There is no statistically significant impact at significance level $(\alpha \leq 0.05)$ for social responsibility with its dimensions (economic, legal, ethical and philanthropic) in Jordanian public shareholding companies on sustainable development

Table 8. Main Hypothesis Test results

\begin{tabular}{llll}
\hline Variables & B & (T) & Sig \\
\hline Economic Responsibility & .095 & 1.278 & .204 \\
Legal Responsibility & .185 & 1.506 & .135 \\
Ethical Responsibility & .459 & 4.187 & .000 \\
Philanthropic Responsibility & .205 & 1.899 & .060 \\
$(\mathrm{R})$ & 0.92 & & \\
$\left(\mathrm{R}^{2}\right)$ & 0.814 & & \\
F Calculated Value & 125.729 & & \\
Sig & 0.000 & & \\
\hline
\end{tabular}

The table indicates that there is a statistically significant impact for social responsibility on sustainable development, since the significance level is (.000.). F calculated value $=125.759$ which is more than the tabulated value (2.37), at a level significance $(\alpha \leq 0.05)$, which also represents the significant of this model. $\left(\mathrm{R}^{2}\right)=$ (0.814) indicates that social responsibility interpret $(81.4 \%)$ of the change in the sustainable development in Jordanian shareholding companies and it is a strong relationship between the variables, because the value of (R) 
$=90.2 \%$. Results of partial analysis for this hypothesis indicates that economic and legal responsibilities did not contribute to sustainable development while ethical and philanthropic responsibility have an influence which appears through the values of (Beta) and values (T) at significant level $(0.05)$ as described in the table. Based on the above, we reject the null hypothesis, and the alternative one is accepted.

Based on: There is a statistically significant impact at significance level $(\alpha \leq 0.05)$ for social responsibility in Jordanian public shareholding companies on sustainable development

\subsection{First sub Hypothesis testing Results}

There is no statistically significant impact at significance level $(\alpha \leq 0.05)$ for economic responsibility in Jordanian public shareholding companies on sustainable development

Table 9. First Sub Hypothesis Test results

\begin{tabular}{llll}
\hline Variables & B & $(\mathrm{T})$ & Sig \\
\hline Economic Responsibility & 0.113 & 2.187 & $* 0.030$ \\
$(\mathrm{R})$ & 0.811 & & \\
$\left(\mathrm{R}^{2}\right)$ & 0.658 & & \\
F Calculated Value & 95.446 & & \\
F Tabulated Value & 2.46 & & \\
Sig & $* 0.00$ & & \\
\hline
\end{tabular}

The table indicates that there is a statistically significant impact that there is a statically significant impact of economic responsibility on sustainable development since the significance level is $(0.00$. $) \mathrm{F}$ calculated value $=95.446 \mathrm{which}$ is more than the tabulated value (2.46), at a level significance $(\alpha \leq 0.05)$, which also represents the significant of this model. $\left(\mathrm{R}^{2}\right)=(0.814)$ indicates that economic responsibility interpret $(81.4 \%)$ of the change in the sustainable development in Jordanian public shareholding companies and it is a strong relationship between the variables, because the value of $(\mathrm{R})=81.1 \%$

Based on, the null hypothesis is rejecte and the alternative one is accepted, this means that there is statistically significant impact of economic responsibility at $(\alpha=0.05)$ level in Jordanian public shareholding companies on sustainable development

\subsection{Second sub Hypothesis Testing Results}

There is no statistically significant impact at significance $(\alpha \leq 0.05)$ level of legal responsibility in Jordanian public shareholding companies on sustainable development

Table 10. Second Sub Hypothesis Test results

\begin{tabular}{llll}
\hline Variables & B & $(\mathrm{T})$ & Sig \\
\hline Legal Responsibility & 65.8 & 12.493 & 0.00 \\
$(\mathrm{R})$ & 0.755 & & \\
$\left(\mathrm{R}^{2}\right)$ & 0.569 & & \\
F Calculated Value & 156.045 & & \\
F Tabulated Value & 2.46 & & \\
Sig & 0.000 & & \\
\hline
\end{tabular}

Table (9) indicated that there is a statically significant impact of legal responsibility on sustainable development. since the significance level is $(0.00)$. F calculated value $=156.045 \mathrm{which}$ is more than the tabulated value (2.46), at a level significance $(\alpha \leq 0.05)$, which also represents the significant of this model. $\left(R^{2}\right)=(0.569)$ indicates that legal responsibility interpret $(46.9 \%)$ of the change in the sustainable development in Jordanian shareholding companies and it is a strong relationship between the variables, because the value of $(R)=75.5 \%$

Based on, the null hypothesis is rejected and the alternative one is accepted this means that there is statistically significant impact of legal responsibility at $(\alpha=0.05)$ level in Jordanian public shareholding companies on sustainable development

\subsection{Third sub-Hypothesis Testing Results}

There is no statistically significant impact at significance $(\alpha \leq 0.05)$ level of ethical responsibility in Jordanian public shareholding companies on sustainable development 
Table 11. Third Sub Hypothesis Test results

\begin{tabular}{llll}
\hline Variables & B & (T) & Sig \\
\hline Ethical Responsibility & 0.827 & 26.659 & 0.000 \\
$(\mathrm{R})$ & 0.885 & & \\
$\left(\mathrm{R}^{2}\right)$ & 0.783 & & \\
F Calculated Value & 426.779 & & \\
F Tabulated Value & 2.46 & & \\
Sig & 0.000 & & \\
\hline
\end{tabular}

Table (10) indicates that there is a statically significant impact of ethical responsibility on sustainable development since the significance level is $(0.00)$. F calculated value $=426.779$ which is more than the tabulated value (2.46), at a level significance $(\alpha \leq 0.05)$, which also represents the significant of this model. $\left(\mathrm{R}^{2}\right)=(0.783)$ indicates that ethical responsibility interpret $(78.3 \%)$ of the change in the sustainable development in Jordanian shareholding companies and it is a strong relationship between the variables, because the value of $(\mathrm{R})=88.5 \%$

Based on, the null hypothesis is rejected and the alternative one is accepted this means that there is statistically significant impact of ethical responsibility at $(\alpha=0.05)$ level in Jordanian public shareholding companies on sustainable development

\subsection{Fourth sub-Hypothesis Testing Results}

There is no statistically significant impact at significance $(\alpha \leq 0.05)$ level of philanthropic ethical responsibility in Jordanian public shareholding companies on sustainable development.

Table 12. Fourth Sub Hypothesis Test results

\begin{tabular}{llll}
\hline Variables & B & (T) & Sig \\
\hline philanthropic Responsibility & 0.813 & 18.317 & 0.000 \\
$(\mathrm{R})$ & 0.860 & & \\
$\left(\mathrm{R}^{2}\right)$ & 0.740 & & \\
F Calculated Value & 355.525 & & \\
F Tabulated Value & 2.46 & \\
Sig & 0.000 & & \\
\hline
\end{tabular}

Table (12) indicates indicated that there is a statically significant impact of philanthropic responsibility on sustainable development since the significance level is $(0.00)$. F calculated value $=355.525$ which is more than the tabulated value (2.46), at a level significance $(\alpha \leq 0.05)$, which also represents the significant of this model. $\left(\mathrm{R}^{2}\right)=$ (0.740) indicates that philanthropic responsibility interpret (74.0\%) of the change in the sustainable development in Jordanian public shareholding companies and it is a strong relationship between the variables, because the value of $(\mathrm{R})=86 \%$

Based on, the null hypothesis is rejected and the alternative one is accepted this means that there is statistically significant impact of philanthropic responsibility at $(\alpha=0.05)$ level in Jordanian public shareholding companies on sustainable development

\section{Results}

-Based on the study data analysis, the study concluded a set of results as follow

-There is a statistically significant impact at the level of significance $(\alpha \leq 0.05)$ of social responsibility in Jordanian shareholding companies on sustainable development

-There is a statistically significant impact at the level of significance $(\alpha \leq 0.05)$ of economic responsibility in Jordanian shareholding companies on sustainable development

-There is a statistically significant impact at the level of significance $(\alpha \leq 0.05)$ of legal responsibility in Jordanian shareholding companies on sustainable development

-There is a statistically significant impact at the level of significance $(\alpha \leq 0.05)$ of ethical responsibility in Jordanian shareholding companies on sustainable development

-There is a statistically significant impact at the level of significance $(\alpha \leq 0.05)$ of philanthropic responsibility in Jordanian shareholding companies on sustainable development 


\section{Recommendations:}

- Shareholding companies in Jordan have to implement social responsibility programs that benefited community and $\mathrm{f}$ companies in order to promote development companies in Jordan

- To promote and raise the level of awareness of all employees knowledge in the public shareholding of the benefits of corporate social responsibility implementation

- Attention should be given to meet community needs in supporting projects that provide jobs for unemployed community

- To increase and enhance cooperation between public share holding companies and those who in charge of development projects to set joint plans for sustain development

\section{Conclusion}

The study aimed to investigate the impact of social responsibility o sustainable development in shareholding companies in Jordan. Many previous studies has tackled this topic in different countries, the current study results revealed There is a an impact of social responsibility in Jordanian shareholding companies on sustainable development (economic responsibility, legal responsibility, ethical responsibility and philanthropic responsibility ).The results confirmed other previous results in this concern

The study was carried out in a developing country and handled the CSR topic and its impact on sustainable development which is considered new research, therefore the major contribution of the current study is concentrated of measuring the impact of CSR on sustainable development through the activities of public shareholding companies which in its turn reveal the role of such companies in country's development

\section{References}

Alosrj, H. A. M. (2015). The social responsibility of the private sector and its role in sustainable development of the Kingdom of Saudi Arabia. Social Science Journal, Eectronic Journal, Ministry of Culture and Information, Saudi Arabia, 1076, 1-19.

Amole Bilqis Bolanle, Adebiyi, Sulaimon Olanrewaju, lanre Awolaja Ayodeji Muyideen. (2012). Corporate Social Responsibility and Profitability of Nigeria Banks - A Causal Relationship. Research Journal of Finance and Accounting, 3(1).

Anselmsson, J., \& Johansson, U. (2007). Corporate Social Responsibility and the Positioning of grocery brands"An exploratory study of retailer and manufacturer brands at point of purchase. International Journal of Retail \& Distribution Management, 35(10), 835-856. http://lup.lub.lu.se/record/1387801

Carrigan, M., \& Attalla, A. (2001). The myth of the ethical consumer - do ethics matter in purchase behaviour? Journal of Consumer Marketing, 18(7), 560-578. http://dx.doi.org/10.1108/07363760110410263

Carrigan, M., \& Attalla, A. (2001). The myth of the ethical consumer - do ethics matter in purchase behavior? Journal of Consumer Marketing, 18(7), 560-577.

Choi, Y., \& Yu, Y. (2014). The influence of perceived corporate sustainability practices on employees and organizational performance. Sustainability, 6, 348-364. doi:10.3390/su6010348

Eliza, S., \&Mani, M. (2013). Corporate Social Responsibility: An Analysis of Indian Commercial Banks. AIMA Journal of Management \& Research, 7(1/4).

Eweje, G., \& Bentley, T. (2006). CSR and staff retention in New Zealand companies literature review. (Department of Management and International Business Research Working Paper series no.6)Auckland, NZ: Massey University. http://hdl.handle.net/10179/635

Heslin, A. P., \& Ochoa, D. J. (2008). Understanding and developing strategic corporate social responsibility. Organizational Dynamics, 37(2), 125-144.

Hiti, S. (2013). Population and Economic Development in Arab World. Dar Al- Manahej for publication and distribution, Amman

Majeda Abu-Zant, \& Ghoneim, O. (2006). Sustainable Development. Its philosophy, planning methods, and measurement tools. Dar Safa'a, Amman.

Mohsin, A. G. T., \& Al-Amiri, S. M. (2005). Social Responsibility and Business Ethics (the business and the community). Dar Wael for publication, I 1, Amman, Jordan.

Nejati, M., \& Ghasemi, S. (2012) Corporate social responsibility in Iran from the perspective of employees. 
Social Responsibility Journal, 8(4), 578-588. http://dx.doi.org/10.1108/17471111211272552

Pava, M. L. (2008). Why Corporations Should Not Abandon Social Responsibility. Journal of Business Ethics, 83(4), 805-812. DOI: $10.1007 / \mathrm{s} 10551-008-9666-7$

Rawabdeh, M. A., \& Ismail, A. R. (2010). Social Responsibility Practicing Level and its application barriers in public institutions in Jordan. Journal of Social Sciences, 38(4).

Riasi, A., \& Pourmiri, S. (2016). Examples of Unsustainable Tourism in Middle East. Environmental Management and sustainable Development, 5(1), 69-85. http//dx.doi.org/10.5296/emsd.v5il.8705

Siwar, C., \& Hossain, M. T. (2009). An Analysis of Islamic CSR Concept and the Opinions of Malaysian Managers. Management of Environmental Quality: An International Journal, 20(3), 290-298., DOI: $10.1108 / 1477783091095068$

Swaidan, N., \& Haddad, S. (2006). Marketing a Contemporary Concepts. Dar Al-Hamed for Publishing and Distribution, Amman, Jordan.

Tanja Brühl Matthias Hofferberth, Burkart, E., Fey, M., \& Peltner, A. (2011). Multinational Enterprises as "Social Actors". Constructivist Explanations for Corporate Social Responsibility Global, 25(2), 205-226, http://dx.doi.org/10.1080/13600826.2011.553533

Valmohammadi, C. (2014). Impact of corporate social responsibility practices on organizational performance: an ISO 26000 perspective. Social Responsibility Journal, 10(3), 455-479. http://dx.doi.org/10.1108/SRJ-02-2013-0021

\section{Copyrights}

Copyright for this article is retained by the author(s), with first publication rights granted to the journal.

This is an open-access article distributed under the terms and conditions of the Creative Commons Attribution license (http://creativecommons.org/licenses/by/4.0/). 